理石病に特異的のむのだろうか？

\section{解 答}

特異的のものではない。

\section{5. 反対咬合中治り昜い数種の症例}

\section{称 正析本 俊夫}

反対咬合中洽㞠容易なるものは所謂仮性の下顎前突 とされて居る。時期的得孚永久菌の混合菌列与に於 ける反対咬合は特に治り易い淀例と考えられ、予後も 文良好である。

夆々は本年 (昭和28年)三月来一四月初旬に来院世

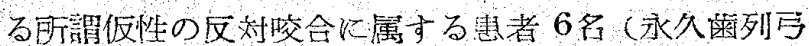

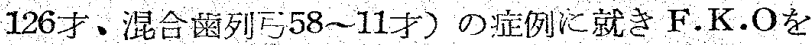

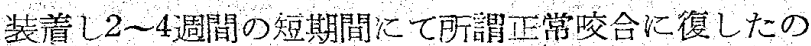
て報告する。

\section{6. 口腔醽母菌症について}

外 久 湶 勝之 山田 長 敵

我々はさきに本徒の数例につき、との口胵領域に於 ける陪床所見の锌細と細菌学的梌索につ報告し。考 按の一端を述べ目つ口腔頜域に於ける本症の発現が我 タの予想以上に参いのではないかとの見解を述べてい

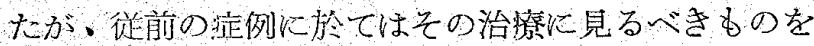
見出せず。子後に関しては一洙の不安が残されてい た。

我タは今回更に本症の一例飞遭遇したので、本例に 対しマイシリン・カーレオマイシン、スト习゚レシトマ イシンなとの抗生物質とグンナアナ紫、ホモスルフア ミンの司可涂布により加療中のところ、現在汽顕著な 效果を得ており、之等の療法が本徒に対し特效的とは 云えないまでも可成りの效果が女るものと考えられる のでその稬要を報告した。

質 問 松下 (医化学)

醮母菌泟と診断した根拠について詳しく知りたい。

\section{解 答}

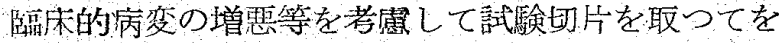
らず。促つて組識内証明が众けてをり・此の点診断 に一洙つ疑義がないとは云えぬが、臨束的細菌学的 㭘索結果より本例が少くとも広義の本泟で岁つた事 は間違いない。通清学的㝊応が陰性であつたとして も。その的中率が偑問題である為。その陰性が必ず しも。本虚否定仙ならない。

\section{質 問 大曲 (細菌)}

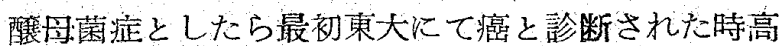
単位「ぺ」削を段分しているが、この事が本泟の誘
因となつたとは考えませんか。

\section{解 答}

本潰瘍が醸母菌性のものか、癌性のものかの最後的 渗定については、病理組識学的検案によるのである が抗生物質使用前後に於ける醅母菌の証明と抗生物 質使用後の沿療的傾向より見て前者と考えられる。

\section{質 問 大曲 (細菌)}

御使用になつた治療剂の中、特に本症に有効だつた と思はれたものはありませんか。有效だつたとした ら、醅母菌汇対して、或いは随伴菌に対して奏効し たか、判りをせんか。

\section{解 答}

現病摩に於ける「へ」剂の大量投分が本病の誘因に なつたのではないかという事は考えられる。

質 問 大曲 (細菌)

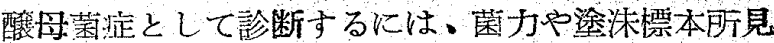
並江血清学的検查等を参考として渗定するわけたが ぞの程度挹やりになりましたか。

\section{解 答}

接生成使用中患者自身としては「オーレオマイシ ン小使用時に於て、食好な感があつたと云了が、何 れが特に有效であつたかの決定は、これらか蠤母菌 自身に作用したか、混合感染に有効であつたのか、 不明である点より決定は今の所出来ない。

\section{Enamel 質酸蝕の電子顯微鏡による観察}

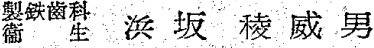

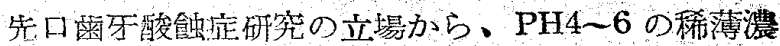
度でも、垛酸、硝酸以より、Enamel 質が各々異つた 溶解性を現わすことを発表した。今回はこれらの無機 酸により、Enamel 質面が沺何ように酸蝕されるか を、電子影微鏡により、組識学的に観察した。資粗は 抜去西牙を用い, N/100 酸液を2分一 4分間作用させ。 フォルスバル法にて Lepulica を調製、1/5投射角にて Cr を蒸着 Shadawing したものを2.500倍の写真に 撮つた。それによると稄柱末端は俯敗像では、個々の 捳立したものではなく、鱗状形の種々な形で現われ、 稜䅅基質は $0,1 \mu$ 前後の石灰化粒子により禥成され。 酸蝕により稜社週線は隆起部として認められるが、あ る一部のものは週緣に副い、陷没部となつて現われた。 酸蝕は初め稜注個々に和いて、基質部を平面的に侵主 が、眭間のたつに従つて、助状より椀状に進むことが 明らか江諗められた。

\section{8. 雬牙の環境衛生学的研究}




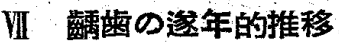

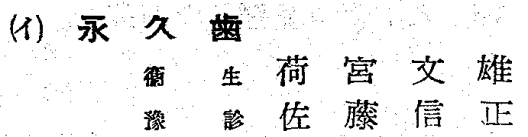

戰後に於ける小中学生の永久苗融蝕の消令的消減の 傾向に就て、九州に於ける8地区の学童6－15おの男 6330 名、女5781名、計 12111 名を調查凟擞として観察 Lた。

この結果を見ると、男女とも前宩部に於ては上顎橉

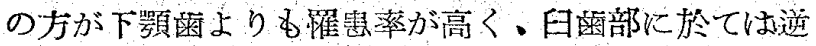
に下顎手の方が高度を示した。

即ち䍜患率を見ると（男十女）に执汀る上顎永久篓

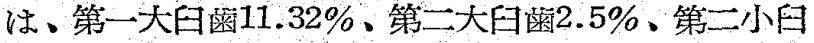

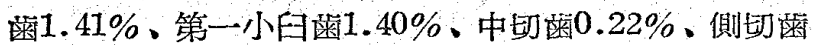

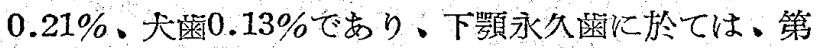

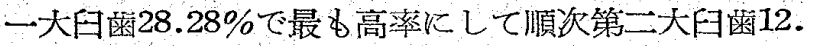

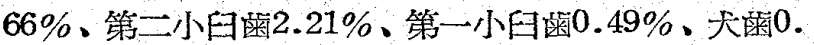

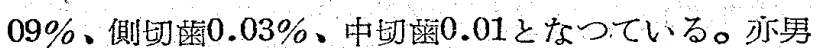
女差て就ては、前菌部に於ては殆んど童は見られない が、日畨部に於ては女が简率を示していた。

向 9 11 才間が各蒾牙罹隐率の上景を見る時期とな つてをり、この時期に於ける適町なる指導に依る菡口

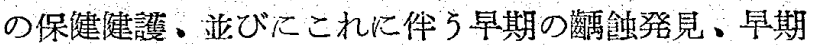
洽潦を特に強張するるのである。

\section{0. 保序領域における化学療法剤について} 保存山本博武・吉田光雄 中 村 默

現在保存領域に主として使用されている化学爒法剤 には、ホースクレゾール (F.C) ・フラシン (F) 、 ペニシリン (P.c)、ストレプトマイシン ( S.M )、テ ラマイシン ( T.M )、オーレオマイシン (A.M) 。

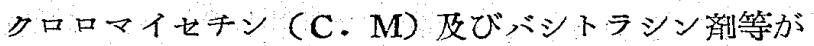
ある。これらの化学療法郕中の抗生物賀が耐性菌を獲 得すると云う事は诸学者の報告によつてす眀であり。

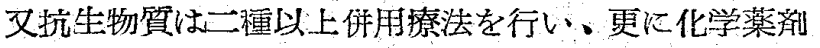
との併用を行つた方が遙かに效果がめると云はれてい る。私共は昭和25年以来、現在までに化学撩法剂の仿 用潦法について試験管内の㬰験並びに陪床成續を九州

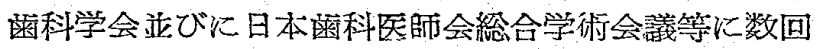
登表を行つた。今回はPC而性のプドウ状球菌に対し て、F、C と抗成物質及び闰時併用に椋ける相関性に つ、て発表をする。

冢験方法は省略壬る。

1. 比較的高度の P C 耐性を有する菌株には P c は
無效であつた。

2. P C 耐性株はF、C、T.M、A.M、C.M等 対する留受性は。P c 感受性株と殆んど視異が認めら れなからた。

3. F、C は他の薬郕より有効に作用した。

4. F.C と抗生物質との同時併用に和いては、相

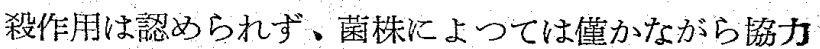
作用が認められた。

佮扣、私其は今後併用橑法についての臨床成續につ いて発素をする。

\section{1. 化学療法剤の根管治療薬の检討（第四報） \\ 「ホルムクレゾール」剤について

保存 山 本 博 武

感染根管の治療には殺菌力が強く而も蔝咸围組織に 為書作用の少い薬削が要求されている今日彷来鬼届刺 哉性を䦕題とされながらす省広く使用されて居る根管 治獠薬「木ルふクレゾール」について本学附属病院保 存部診橑録 355 例儿就き統計罆察をした。 全例 355 例

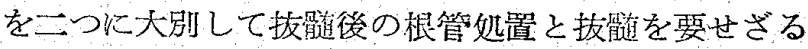

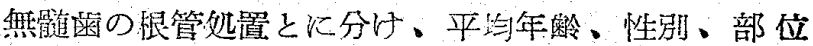
別に分熲すると何れる平均年秢三十才前後男性儿比し

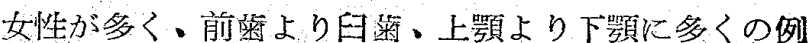
数を証める。技髄啳の根管如置に就て見ると F.C. の及使用して94\%の根充率 1.6 回の平均治潦回数を 示し他の抗生物質との保用例に於ては $81 \%$ の根充率 2.7回の平均治撩回数を示す。洽憭中総例は F.C.の

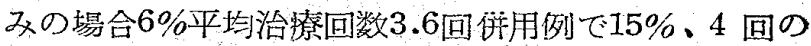
平均治燎回数を示す。無艏圈の根管処置例に於ては永 久菌に於て F.C.のみの場合 $69 \%$ の根充率、4.8回、 併用例に於ては64\%、5.1回となり治潦中秝例は夫々2 $2 \% 、 24 \%$ 、他は抜業の予媵を示して居る乳憐に於て は F.C.のみの場合 $28 \%$ 根充率傡用の場合は $11 \%$ を示し他は高率の沿撩中緿を示して居る。以上甚だ粗 略な統阡に依り日常禁々が行つて居る根管如置を收省 して見ると在来から使用に馿れた F.C.の果してい る役割の大且つ良なの結果を琴々に提供しつつあるを 見る。

\section{買、問，荷宮（䇺生)}

歯髄の洽橑時、薬物による予後観察は薬物実効日数 による比較检討が沿療回数よりも正しい成績が得ら れると思5。

\section{解 答}

御說もつともでありまして今後のデーターに笑效日 